\title{
STRATEGI PENGEMBANGAN POTENSI KULINER LOKAL DALAM MENUNJANG DESA WISATA EKOLOGIS (DWE) DI DESA NYAMBU KEDIRI, TABANAN
}

\author{
A. A. Ketut Sri Candrawati \\ Email: agungcandra48187@gmail.com \\ Politeknik Internasional Bali \\ A. A. Nyoman Sri Wahyuni \\ Email: yuniagung1407@gmail.com \\ STISIP Margarana Tabanan
}

\begin{abstract}
The culinary potential of Nyambu Village cannot be seen if tourists visit and travel alone in Nyambu Village to enjoy local food. After tourists take the DWE tour package in Nyambu Village, local food is served by the Ecological Tourism Village (DWE) in Nyambu Village for guests visiting DWE in Nyambu village. The purpose of this study is to determine the development strategy and implications of developing local culinary potential in supporting the Ecological Tourism Village (DWE) in Nyambu Kediri Village, Tabanan. This study used descriptive qualitative method. The data was collected by means of observation techniques, in-depth interview techniques, and document study. The collected data were analyzed using SWOT analysis techniques, verified (data display), and concluded in narration, tables, photos, and charts. The theory used is Community Based Tourism (CBT) and the Theory of Tourist Attraction.

The strategy for developing local culinary potential in supporting DWE in Nyambu Kediri Village, Tabanan is determined through a SWOT analysis and a SWOT analysis matrix, as follows: SO (StrengthOpportunity) strategy, namely a strategy to develop local culinary potential and a tourism village development strategy; WO (WeaknessesOpportunity) strategy, namely the strategy for the formation of local culinary management groups / organizations and CBT development strategies; ST (Strength-Threats) Strategy, namely a strategy to increase cooperation in the culinary field and a strategy to increase promotion; WT (Weaknesses-Threats) strategy, which is a strategy to increase stakeholder support for the formation of local culinary groups. The implications of developing culinary potential for local culinary processors, DWE and the people of Nyambu Village are enormous. The greater the support from the stakeholders, the greater the local culinary potential in Nyambu Village, and vice versa.
\end{abstract}

Keywords: Development Strategy, Local Culinary Potential, Ecological Tourism Village 


\begin{abstract}
Abstrak
Potensi kuliner yang dimiliki oleh Desa Nyambu, tidak terlihat jika wisatawan berkunjung dan keliling sendiri di Desa Nyambu untuk menikmati makanan lokal. Setelah wisatawan mengambil paket wisata DWE di Desa Nyambu, makanan lokal disajikan oleh Desa Wisata Ekologis (DWE) di Desa Nyambu untuk tamu yang berkunjung ke DWE di desa Nyambu. Tujuan penelitian ini yaitu untuk mengetahui strategi pengembangan dan implikasi pengembangan potensi kuliner lokal dalam menunjang Desa Wisata Ekologi (DWE) di Desa Nyambu Kediri, Tabanan. Penelitian ini menggunakan metode deskriptif kualitatif. Teknik yang digunakan dalam pengumpulan data, yaitu teknik observasi, teknik wawancara mendalam, dan studi dokumen. Data yang terkumpul dianalisis menggunakan teknik analisis SWOT, diverifikasi (display data), dan disimpulkan dalam narasi, tabel, foto, dan bagan. Ada dua teori yang digunakan dalam penelitian ini, yaitu Community Based Tourism (CBT) dan Teori Daya Tarik Wisata.

Strategi pengembangan potensi kuliner lokal dalam menunjang DWE di Desa Nyambu Kediri, Tabanan ditetapkan melalui analisis SWOT dan matriks analisis SWOT, sebagai berikut: Strategi SO (StrengthOpportunity), yaitu strategi pengembangan potensi kuliner lokal dan strategi pengembangan desa wisata; Strategi WO (WeaknessesOpportunity), yaitu strategi pembentukan kelompok/ organisasi pengelola kuliner lokal dan strategi pengembangan CBT; Strategi ST (StrengthThreats), yaitu strategi meningkatkan kerjasama dibidang kuliner dan strategi peningkatan promosi; Strategi WT (Weaknesses-Threats), yaitu strategi meningkatkan dukungan stakeholders terhadap terbentuknya kelompok kuliner lokal. Implikasi pengembangan potensi kuliner terhadap pengolah kuliner lokal, DWE dan masyarakat Desa Nyambu sangat besar. Semakin besar dukungan stakeholders semakin meningkat potensi kuliner lokal di Desa Nyambu, begitu juga sebaliknya.
\end{abstract}

Kata Kunci: Strategi Pengembangan, Potensi Kuliner Lokal, Desa Wisata Ekologis

\title{
1. Pendahuluan
}

Bali merupakan salah satu tujuan wisata, baik wisatawan asing maupun wisatawan domestik. Undang-undang terkait pariwisata yaitu Undang-undang Nomor 10 Tahun 2009 tentang Kepariwisataan. 
Pengembangan pariwisata diseluruh kabupaten di Bali termasuk Kabupaten Tabanan terus digalakan melalui pengembangan desa Wisata.

Kabupaten Tabanan memiliki 23 Desa Wisata, termasuk dua Desa ekowisata, yaitu Desa Jatiluwih dan Desa Nyambu. Desa Nyambu ditetapkan menjadi desa wisata dengan Surat Keputusan (SK) Bupati Tabanan Nomor 180/327/03/HK \& HAM/2016, Tentang Desa Nyambu sebagai Desa Wisata di Tabanan, pada tanggal 31 Oktober 2016. Secara geografis wilayah Desa Nyambu memiliki areal persawahan lebih dari $60 \%$ dari total luas wilayah. Areal persawahan tersebut terbentang luas di sisi kiri dan kanan jalan raya Dakdakan - Munggu.

Desa Wisata Ekologis Desa Nyambu bisa diluncurkan tanggal 29 April 2016. Setelah Desa Wisata Ekologi dibuka, selanjutnya masyarakat harus memahami seluruh potensi yang dimiliki, termasuk potensi kuliner yang diangkat dalam penelitian ini serta mampu mempertahankan potensi yang dimiliki oleh desa wisata ekologi di Desa Nyambu Kediri, Tabanan agar pariwisata bisa berkelanjutan. Potensi kuliner yang dimiliki oleh Desa Nyambu ada beberapa macam, seperti Kripik Belut, Sate Tuna, Sate Ayam, Sate Babi, Jajan Bali dan Teh sereh, namun kalau keliling di Desa Nyambu tidak kelihatan ada makanan lokal yang biasa disajikan oleh Desa Wisata Wisata (DWE) di Desa Nyambu untuk tamu yang berkunjung ke DWE di desa Nyambu. Tujuan penelitian ini yaitu untuk mengetahui strategi pengembangan dan implikasi pengembangan lokal dalam menunjang Desa Wisata Ekologi (DWE) di Desa Nyambu Kediri, Tabanan.

\section{Konsep dan Teori}

Bagian ini dibagi menjadi dua, yaitu konsep dan teori agar memudahkan pembaca dalam memahami isi dari artikel ini. 


\subsection{Konsep}

Terdapat tiga konsep penting dalam artikel ini, yaitu strategi pengembangan, potensi kuliner lokal dan Desa Wisata Ekologis (DWE). Konsep strategi yang digunakan dalam penelitian ini, yaitu konsep strategi Pearce II dan Robinson (2008:2), yang menyatakan strategi adalah rencana berskala besar, dengan orientasi masa depan, guna berinteraksi dengan kondisi persaingan untuk mencapai tujuan perusahaan. Pengembangan dalam penelitian ini difokuskan pada strategi pengembangan dalam bidang pariwisata. Konsep pengembangan yang digunakan dalam penelitian ini, yaitu konsep pengembangan dari Suwantoro (1997: 56) pengembangan adalah upaya memajukan atau memperbaiki sesuatu yang telah ada, yang bertujuan untuk mengembangkan suatu produk dan pelayanan menjadi berkualitas, seimbang dan bertahap.

Endra K Pihadhi (2004: 6) potensi adalah kekuatan, energi, atau kemampuan yang terpendam yang dimiliki dan belum dimanfaatkan secara optimal. Strategi pengembangan dalam penelitian ini adalah menyusun rencana integratif khususnya dalam membuat strategi pengembangan potensi kuliner lokal dalam menunjang Desa Wisata Ekologi (DWE) di Desa Nyambu Kediri, Tabanan, dengan melibatkan peran dari pihak pemerintah maupun swasta sehingga komitmen yang terbentuk dapat memberikan kemampuan daya saing untuk terus berkembang dan memberikan manfaat bagi masyarakat Desa Nyambu.

\subsection{Teori}

Dalam membahas strategi pengembangan potensi kuliner lokal dalam mendukung DWE di Desa Nyambu penulis menggunakan teori pariwisata berbasis masyarakat atau dikenal dengan Community Based Tourism (CBT) dari Murphy dan teori daya tarik wisata dari Yoeti. Teori 
daya tarik wisata adalah hal yang perlu diperhatikan dalam pengembangan suatu daerah menjadi suatu daerah tujuan wisata agar dapat menarik untuk dikunjungi oleh wisatawan, tujuan wisata harus memenuhi tiga syarat yaitu: daerah harus mempunyai something to see, something to do dan something to buy.

\section{Metode Penelitian}

Penelitian ini menggunakan metode deskriptif kualitatif. Metode penelitian deskriptif menurut Hasan (2002: 22) adalah mencari teori, bukan menguji teori. Pengumpulan data dalam penelitian ini dilakukan dengan wawancara, observasi, dan studi pustaka. Data yang terkumpul dianalisis menggunakan teknik analisis SWOT, diverifikasi (display data), dan disimpulkan dalam narasi, tabel, foto, dan bagan. Analisis yang digunakan adalah analisis SWOT dari Rangkuti (2015: 22) yaitu metode perencanaan strategis yang digunakan untuk mengevaluasi kekuatan (strength), kelemahan (weakness), peluang (oppotunities), dan ancaman (threat) dalam suatu proyek atau suatu spekulasi bisnis.

\section{Hasil dan Pembahasan}

Analisis SWOT Strategi Pengembangan Potensi Kuliner Lokal Dalam Menunjang DWE di Desa Nyambu Kediri, Tabanan, berdasarkan kekuatan, kelemahan, peluang dan ancaman pengembangan potensi kuliner lokal yang dimiliki oleh DWE di Desa Nyambu Kediri, Tabanan. Kekuatan potensi kuliner lokal DWE di Desa Nyambu, yaitu unik dan khas (sate lilit tuna, ayam, babi; kripik belut; keripit beras), serta sudah ada organisasi/ badan pengelola. Contoh makanan yang disajikan seperti pada gambar di bawah ini. 


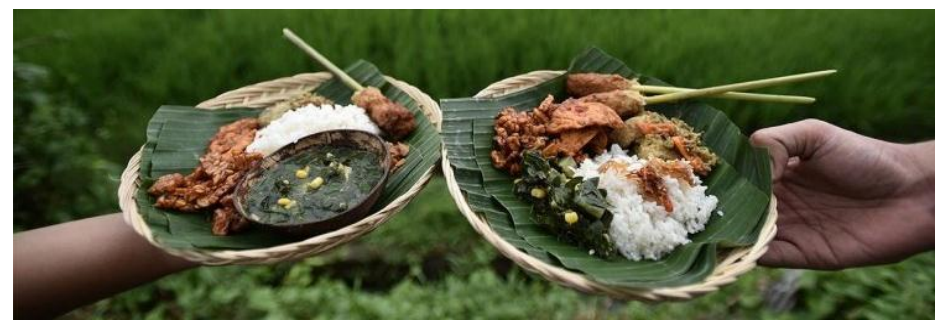

Gambar 1. Makanan di DWE Desa Nyambu

Sumber: (jed.or.id)
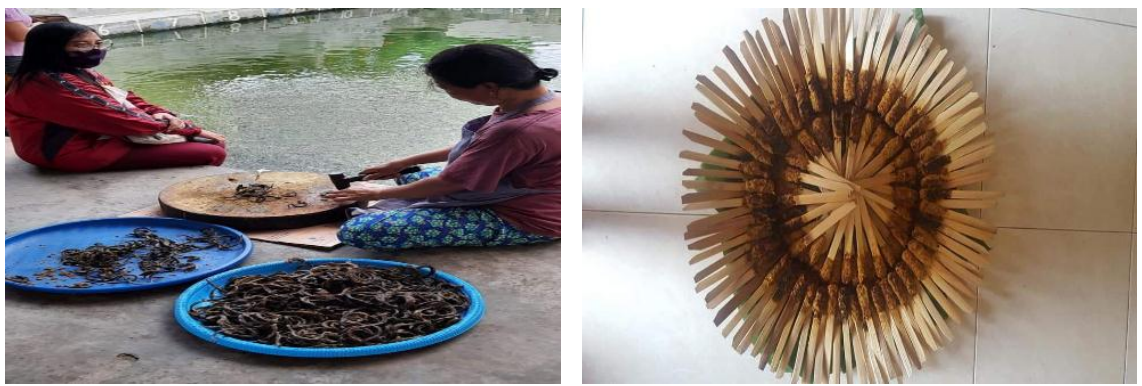

Gambar 2. Pengolahan Kripik Belut Dan Sate Lilit Matang

Sumber: penulis Tahun 2020

Hasil wawancara yang dilakukan dengan Yeni manajer DWE

Desa Nyambu, mengatakan:

Selama ini pengurus DWE Desa Nyambu menyajikan menu sate lilit, sayur kelor, sayur gondo, ayam Gerang asem, sambel matah, sambel embe dan be lindung (belut)/ lindung mecakcak, serta welcome drink-nya teh sereh. Masakan biasanya disiapkan sama ibu-ibu team food \& beverage. Bahan sate dibeli di Banjar Carik Padang, belut biasanya dibeli yang masih mentah terus di olah sendiri. Teh sereh bahannya cukup air, gula sama sereh. Serehnya digeprek, direbus bersama gula hingga mendidih dan warnanya berubah kecoklatan (Yeni, 28 November 2020).

Hasil wawancara dengan Biasa sebagai perbekel Desa Nyambu sekaligus pengusaha sate lilit mengatakan bahwa:

Sate lilit merupakan kuliner yang unik dan khas. Dalam upacara Agama Hindu diperlukan sate lilit, baik untuk dikosumsi, untuk upacara maupun untuk caru (Bhuta Kala). Masyarakat sering membeli sate lilit yang sudah matang dipanggang atau digoreng, dan ada juga membeli luluh sate untuk dipanggang di rumah masing-masing. Pemanfaatan sate lilit untuk konsumsi maupun untuk upacara mendorong penjualan sate lilit/ luluh sate mengingkat (Biasa, 31 Oktober 2020) 
Sekitar tahun 2015 Poklahsar Taman Griya mendapat pembinaan administrasi, cara pengolahan dan pemasaran dari Dinas Perikanan dan Kelautan Tabanan. Disamping dukungan oleh Dinas Perikanan dan Kelautan Tabanan, Poklahsar Taman Griya juga mendapat dukungan dari Bumda dan Perusda Tabanan dibidang pemasaran. Poklahsar Taman Griya juga mengurus Standar Nasional Indonesia (SNI) keripik belut, untuk mendukung pemasarannya.

Bumda memperlancar pemasaran keripik belut, karena bumda memesan sampai $50 \mathrm{~kg}$ bahkan lebih, sehingga produksi keripik Belut menjadi lancar. Perkembangan dari Poklahsar Taman Griya semakin maju, sehingga beberapa kali mendapatkan juara dan Ketuanya Ida Bagus Parwata beberapa kali menjadi nara sumber dan mendapat penghargaan dari berbagai perlombaan.

Tabel 1.

Penghargaan Poklahsar Taman Griya Tahun 2016

\begin{tabular}{|c|l|c|}
\hline No & \multicolumn{1}{|c|}{ Katagori Perlombaan } & Pemenang \\
\hline 1 & $\begin{array}{l}\text { Lomba Usaha Mikro Kecil Dan Menengah } \\
\text { (UMKM) Pengolahan Terbaik Tingkat } \\
\text { Provinsi Bali Tahun 2016 }\end{array}$ & Juara 1 \\
\hline 2 & $\begin{array}{l}\text { Katagori Skala Kecil Lomba UPI Terbaik } \\
\text { Tingkat Nasional Tahun 2016 }\end{array}$ & Juara III \\
\hline
\end{tabular}

Sumber: Poklahsar Taman Griya Tahun 2020

Kelemahan potensi kuliner lokal DWE di Desa Nyambu, yaitu tidak semua potensi lokal ada organisasi/badan pengelola dan terbatasnya potensi lokal di Desa Nyambu. Potensi kuliner lokal yang memiliki badan pengelola hanya pengelolaan keripik belut. Potensi kuliner lokal seperti sate/ luluh sate yang dikelola oleh beberapa masyarakat Banjar Carik Padang tidak memiliki Badan Pengelola, hanya sempat membentuk kelompok dan mendapat pelatihan dari Dinas Perikanan dan Kelautan Tabanan.

Hasil wawancara dengan Biasa sebagai salah satu pengusaha sate lilit/ lulur sate mengatakan bahwa: 
Banyak kelompok yang dibina saat itu, tapi sebenarnya semua usaha pribadi, sehingga tenaga kerja sebagai anggota kelompok. Pembinaan dilakukan oleh Dinas Perikanan dan Kelautan Tabanan. Kelompok yang dibina setelah mandiri akan dilepas untuk berusaha sendiri. Sekarang sudah banyak yang memiliki usaha sate lilit dan luluh sate di Banjar Carik Padang, Desa Nyambu. (Biasa, 31 Oktober 2020).

Terbatasnya kuliner lokal di Desa Nyambu karena Pemerintah Desa, Pengurus DWE Desa Nyambu dan masyarakat di Desa Nyambu belum menggali potensi kuliner lokal secara maksimal. Dilihat dari desa wisata lainnya, seperti Desa Wisata Bongan sudah memiliki teh gonda, keripik gonda, keripik batang pisang, keripik pare dan kripik kacang. Desa Timpag sudah memiliki kripik Gonda. Desa Nyambu hanya menyajikan Gonda sebagai sayur yang bisa dinikmati saat makan siang di DWE Desa Nyambu, sehingga wisatawan yang berkunjung ke DWE Desa Nyambu, hanya bisa membeli souvenir berupa sabun natural yang dibuat oleh pengurus DWE Desa Nyambu dan keripik belut yang diolah oleh Poklahsar Taman Griya.

Hasil wawancara yang dilakukan dengan Yeni manajer DWE Desa Nyambu terkait souvenir yang bisa dibeli wisatawan di DWE Desa Nyambu, mengatakan:

Pengurus DWE Desa Nyambu menyiapkan sabun natural yang dibuat sendiri sebagai souvenir yang bisa dibeli oleh wisatawan saat berkunjung ke DWE Desa Nyambu. Disamping itu kebetulan juga ada warga nyambu yang punya usaha olahan belut, guide DWE Desa Nyambu mengajak wisatawan mampir ke Poklahsar Taman Griya untuk membeli oleh-oleh keripik belut (Yeni, 28 November 2020).

Peluang potensi kuliner lokal DWE di Desa Nyambu, yaitu dapat meningkatkan perekonomian dan memberdayakan masyarakat yang menunjang DWE di Desa Nyambu. Dari sudut ekonomi, perkembangan kuliner lokal akan menumbuhkan usaha-usaha ekonomi yang saling merangkai dan menunjang kegiatannya sehingga dapat menyerap tenaga kerja sehingga meningkatkan pendapatan masyarakat di Desa Nyambu. 
Potensi kuliner lokal jika digali secara maksimal akan sangat mendukung DWE di Desa Nyambu Kediri, Tabanan. Potensi kuliner lokal yang telah berkembang dan masih bisa ditemukan di Desa Nyambu yaitu sate lilit, keripik belut dan kerupuk beras. Potensi kuliner lokal walaupun tidak banyak sudah bisa mendukung DWE di Desa Nyambu.

Ancaman potensi kuliner lokal DWE di Desa Nyambu, yaitu hilangnya dukungan stakeholder kuliner dan adanya persaingan dengan Desa Wisata lain. Hilangnya dukungan stakeholder akan mengancam perkembangan potensi kuliner lokal di Desa Nyambu. Dukungan sebelumnya diperoleh dari Dinas Perikanan dan Kelautan Kabupaten Tabanan, Bumdes serta Perusda Kabupaten Tabanan. Dinas Perikanan dan Kelautan Kabupaten Tabanan memberikan pelatihan kepada masyarakat, namun pelatihan yang tidak berkelanjutan menyebabkan usaha kuliner lokal tidak berkembang dan menyebabkan masyarakat kurang menggali potensi kuliner lokal yang lain. Dukungan Bumdes dan Perusda yang menurun, menyebabkan pemasaran kuliner lokal menjadi berkurang dan tenaga kerja yang diperlukan dalam mengolah kuliner lokal juga berkurang, sehingga beberapa masyarakat kehilangan pekerjaan.

Wawancara dengan Parwata selaku ketua Poklahsar Taman Griya, menyatakan:

Anggota Poklahsar Taman Griya dulu sebanyak 10 orang, sekarang kosong. Perhatian dari pemerintah kurang, pemasaran juga susah sehingga anggota tidak ada. Sekarang yang ada hanya usaha pribadi yang berusaha bertahan dengan modal sendiri. Kalau dulu masih lancar pemesanan dari Bumda sampai $50 \mathrm{~kg}$ kadang lebih, sehingga produksi kuliner lokal berupa keripik belut lancar. Pemesanan dari Perusda juga menurun, sehingga produksi terus menurun (Parwata, 26 Desember 2020).

Banyaknya pesaing pariwisata dengan fasilitas yang baik tentu menjadi ancaman berarti bagi desa wisata untuk dapat bersaing dengan desa wisata lain di Kabupaten Tabanan atau di daerah-daerah lain. Misalnya DWE di Desa Nyambu ini terkenal sebagai desa yang memiliki 
susur budaya unik dan susur sawah dengan berbagai macam aktivitas, seperti

bersepeda, melukis dan menonton drama serta tari-tarian.

Strategi pengembangan potensi kuliner lokal dalam menunjang

DWE Di Desa Nyambu Kediri, Tabanan ditetapkan melalui analisis SWOT

dan matriks analisis SWOT, seperti tabel 2.

Tabel 2.

Matriks Analisis SWOT Pengembangan Potensi Kuliner di DWE Desa Nyambu

\begin{tabular}{|c|c|c|}
\hline & $\begin{array}{l}\text { Kekuatan (Strengths) } \\
\text { 1) Potensi kuliner lokal unik dan } \\
\text { khas } \\
\text { 2) Sudah ada organisasi atau } \\
\text { badan pengelola potensi kuliner } \\
\text { lokal }\end{array}$ & $\begin{array}{l}\text { Kelemahan (Weaknesses) } \\
\text { 1) Tidak semua potensi kuliner lokal } \\
\text { ada organisasi atau badan } \\
\text { pengelola. } \\
\text { 2) Terbatasnya potensi kuliner } \\
\text { lokal di Desa Nyambu }\end{array}$ \\
\hline $\begin{array}{l}\text { Peluang } \\
\text { (Opportunities) } \\
\text { 1) Dapat } \\
\text { meningkatkan } \\
\text { perekonomian } \\
\text { dan } \\
\text { memberdayakan } \\
\text { masyarakat } \\
\text { 2) Dapat menunjang } \\
\text { DWE di Desa } \\
\text { Nyambu }\end{array}$ & $\begin{array}{l}\text { Strategi S-O } \\
\text { 1) S (1) Potensi kuliner lokal unik } \\
\text { dan khas } \\
\text { 2) O (1) Dapat meningkatkan } \\
\text { perekonomian dan } \\
\text { memberdayakan masyarakat } \\
\text { Desa Nyambu } \\
\text { Strategi: } \\
\text { Pengembangan Potensi Kuliner } \\
\text { Lokal } \\
\text { 1) S (2) Potensi Kuliner lokal } \\
\text { sudah ada organisasi atau } \\
\text { badan pengelola } \\
\text { 2) O (2) Dapat menunjang DWE } \\
\text { di Desa Nyambu } \\
\text { Strategi: } \\
\text { Pengembangan Desa Wisata }\end{array}$ & $\begin{array}{l}\text { Strategi W-O } \\
\text { 1) W (1) Tidak semua potensi } \\
\text { kuliner lokal ada organisasi atau } \\
\text { badan pengelola } \\
\text { 2) O (2) Dapat menunjang DWE di } \\
\text { Desa Nyambu } \\
\text { Strategi: } \\
\text { Pembentukan kelompok/organisasi } \\
\text { pengelola } \\
\text { 1) W (2) Terbatasnya Potensi } \\
\text { kuliner lokal di Desa Nyambu } \\
\text { 2) O (1) Dapat meningkatkan } \\
\text { perekonomian dan } \\
\text { memberdayakan masyarakat Desa } \\
\text { Nyambu } \\
\text { Strategi: } \\
\text { Pengembangan Community Based } \\
\text { Tourism (CBT) }\end{array}$ \\
\hline $\begin{array}{ll}\begin{array}{c}\text { Ancaman } \\
\text { (Threats) }\end{array} \\
\text { 1) }\end{array}$ & $\begin{array}{l}\quad \text { Strategi S-T } \\
\text { 1) S (1) Potensi kuliner lokal Desa } \\
\text { Nyambu unik dan khas } \\
\text { 2) T (1) Hilangnya dukungan } \\
\text { stakeholder kuliner } \\
\text { Strategi: } \\
\text { Meningkatkan Kerjasama dibidang } \\
\text { kuliner } \\
\text { 1) S (2) Potensi Kuliner lokal } \\
\text { sudah ada organisasi atau } \\
\text { badan pengelola } \\
\text { 2) T (2) Adanya persaingan } \\
\text { Desa Wisata lain } \\
\text { Strategi: } \\
\text { Peningkatan promosi }\end{array}$ & $\begin{array}{l}\text { Strategi W-T } \\
\text { 1) W (1) Tidak semua potensi } \\
\text { kuliner lokal ada organisasi } \\
\text { atau badan pengelola } \\
\text { 2) T (1) Hilangnya dukungan } \\
\text { stakeholder kuliner } \\
\text { Strategi: } \\
\text { Menikangkatkan dukungan } \\
\text { stakeholders terhadap terbentuknya } \\
\text { kelompok kuliner lokal } \\
\text { 1) W (2) Terbatasnya potensi } \\
\text { kuliner lokal di Desa Nyambu } \\
\text { 2) T (2) Adanya persaingan Desa } \\
\text { Wisata lain } \\
\text { Strategi: } \\
\text { Menggali potensi kuliner lokal } \\
\text { dalam mendukung Desa Wisata. }\end{array}$ \\
\hline
\end{tabular}


Strategi pengembangan potensi kuliner lokal dalam menunjang DWE di Desa Nyambu Kediri, Tabanan ditetapkan melalui analisis SWOT dan matriks analisis SWOT, sebagai berikut:

a. Strategi SO (Strength-Opportunity), yaitu strategi pengembangan potensi kuliner lokal dan strategi pengembangan desa wisata.

b. Strategi WO (Weaknesses-Opportunity), yaitu strategi pembentukan kelompok/ organisasi pengelola kuliner lokal dan strategi pengembangan CBT.

c. Strategi ST (Strength-Threats), yaitu strategi meningkatkan kerjasama dibidang kuliner dan strategi peningkatan promosi.

d. Strategi WT (Weaknesses-Threats), yaitu strategi meningkatkan dukungan stakeholders terhadap terbentuknya kelompok kuliner lokal.

Implikasi pengembangan potensi kuliner lokal dalam menunjang Desa Wisata Ekologi (DWE) di Desa Nyambu Kediri, Tabanan terhadap kelompok pengelola kuliner lokal, masyarakat maupun DWE di Desa Nyambu sangat besar. Pengertian implikasi menurut Hassan Shadily (ed), dalam Ensiklopedi Indonesia adalah menyelinapkan, mengimbuh. Dengan demikian, implikasi dapat dipahami sebagai keterlibatan stakeholder dalam pengembangan potensi kuliner lokal dalam mendukung DWE di Desa Nyambu Kediri, Tabanan. Stakeholders yang dimaksud di sini, yaitu Dinas Perikanan dan Kelautan Tabanan, Bumda dan Perusda Tabanan, pemerintahan desa, DWE, pihak swasta dan masyarakat.

Implikasi perkembangan potensi kuliner lokal terhadap kelompok pengolah kuliner lokal di Desa Nyambu sangat besar sekali. Hal ini terlihat saat Dinas Perikanan dan Kelautan Tabanan memberikan pembinaan administrasi, pengolahan dan pemasaran terhadap UKM dalam pembuatan bakso, naget dan sate lele. Walaupun tidak berjalan dengan lancar dalam mengolah lele, tetapi beberapa masyarakat Banjar Carik Padang menggunakan ilmunya dalam mengolah lele untuk mengolah sate ayam, 
babi dan bebek sehingga beberapa masyarakat Banjar Carik Padang menjadi pengusaha sate lilit dan luluh sate. Implikasi pengembangan potensi lokal terhadap Kelompok Pengolah dan Pemasar (Poklahsar) Taman Griya yang mengolah keripik belut sangat besar karena dukungan dari Dinas Perikanan dan Kelautan Tabanan, Bumda dan Perusda Tabanan serta anggota kelompok sehingga penjualan meningkat dan Poklahsar memperoleh juara I pada lomba Usaha Mikro Kecil dan Menengah (UMKM) pengolahan terbaik tingkat Provinsi Bali Tahun 2016. Perlombaan skala kecil lomba UPI Terbaik tingkat nasional Tahun 2016, mendapat juara III.

Setelah dianggap mandiri, pembinaan tidak dilakukan kembali oleh Dinas Perikanan dan Kelautan Tabanan, serta dukungan Bumda dan Perusda Tabanan dibidang pemasaran menurun sehingga Poklahsar Taman Griya mengalami penurunan produksi. Bahan belut yang didatangkan dari Jawa harganya mahal, sulitnya memasarkan produk keripik belut dan dukungan dibidang pemasaran yang menurun dari Bumda dan Perusda Tabanan menyebabkan Poklahsar Taman Griya anggotanya menjadi tidak ada. Pengusaha keripik belut hanya dikelola oleh ketua Poklahsar dengan usahanya sendiri, dan memanggil pegawai jika diperlukan.

Implikasi perkembangan potensi lokal terhadap DWE di Desa Nyambu Kediri, Tabanan. Perkembangan potensi kuliner lokal terhadap DWE di Desa Nyambu Kediri, Tabanan sangat besar karena kuliner lokal disajikan kepada wisatawan yang mengambil paket wisata di DWE Desa Nyambu, seperti sate lilit, sayur kelor, sayur gondo, ayam Gerang asem, sambel matah, sambel embe dan be lindung (belut), serta welcome drinknya teh sereh. Disamping itu guide DWE di Desa Nyambu biasanya mengantar tamunya ke Poklahsar Taman Griya untuk melihat cara pengolahan keripik belut serta membeli oleh-oleh keripik belut dan krupuk 
beras, sehingga kemajuan DWE di Desa Nyambu sangat mendukung kuliner lokal yang ada di Desa Nyambu.

Implikasi perkembangan potensi lokal terhadap Masyarakat di Desa Nyambu Kediri, Tabanan sangat besar terkait peluang tenaga kerja dan peningkatan pendapatan. Perkembangan potensi kuliner lokal juga sangat mempengaruhi masyarakat Desa Nyambu, karena perkembangan potensi kuliner lokal dilakukan dengan memberdayakan masyarakat sesuai dengan penelitian Sri Wahyuni yang berjudul Pemberdayaan Masyarakat Dalam Pengembangan Desa Nyambu, Journey, Volume 3, Nomor 1, Desember 2020. Pada penelitian Sri Wahyuni, mulai tahun 2015 -2018 dilakukan pemberdayaan masyarakat dengan berbagai pelatihan untuk meningkatkan pelayanan di DWE Desa Nyambu, namun pelatihan yang dilakukan untuk mempersiapkan DWE Desa Nyambu, bukan pengembangan potensi kuliner lokal. Semakin berkembang kuliner lokal semakin banyak masyarakat di Desa Nyambu yang bisa bekerja dalam kelompok maupun perorangan sehingga mempengaruhi perekonomian masyarakat Desa Nyambu. Banjar Carik Padang beberapa orang memiliki usaha sate lilit dan luluh sate, begitu pula pengolahan keripik belut. Semakin banyak produksi keripik belut semakin banyak pula tenaga kerja yang diperlukan begitu pula sebaliknya, menurunnya produksi keripik belut mengurangi tenaga kerja.

\section{Simpulan dan Rekomendasi}

Strategi pengembangan potensi kuliner lokal dalam menunjang DWE di Desa Nyambu Kediri, Tabanan ditetapkan melalui analisis SWOT dan matriks analisis SWOT, sebagai berikut:

a. Strategi SO (Strength-Opportunity), yaitu strategi pengembangan potensi kuliner lokal dan strategi pengembangan desa wisata. 
b. Strategi WO (Weaknesses-Opportunity), yaitu strategi pembentukan kelompok/ organisasi pengelola kuliner lokal dan strategi pengembangan CBT.

c. Strategi ST (Strength-Threats), yaitu strategi meningkatkan kerjasama dibidang kuliner dan strategi peningkatan promosi.

d. Strategi WT (Weaknesses-Threats), yaitu strategi meningkatkan dukungan stakeholders terhadap terbentuknya kelompok kuliner lokal.

Implikasi pengembangan potensi kuliner terhadap pengolah kuliner lokal di DWE Desa Nyambu dan masyarakat Desa Nyambu sangat besar sehingga banyak berkembang usaha sate lilit dan luluh sate di Banjar Carik Padang serta kelompok Poklahsar Taman Griya dapat berkembang cepat sehingga mendapat juara I pada lomba Usaha Mikro Kecil dan Menengah (UMKM) pengolahan terbaik tingkat Provinsi Bali Tahun 2016. Juara III dalam perlombaan skala kecil lomba UPI terbaik tingkat nasional Tahun 2016. Surutnya dukungan pemerintah Kabupaten Tabanan dan pihak swasta menyebabkan Poklasar Taman Griya yang mengolah keripik belut mengalami kebangkrutan, dari 10 tenaga kerja menjadi 2 orang saja karena modal dan pemasaran terus menurun, kesempatan kerja masyarakat menurun yang mempengaruhi ekonomi masyarakat Desa Nyambu.

Rekomendasi yang penulis dapat berikan untuk Pemerintahan Desa Nyambu dan DWE di Desa Nyambu, yaitu: aparat pemerintahan Desa dan pengurus DWE Desa Nyambu selalu berkoordinasi dengan Pemerintah Kabupaten Tabanan dalam meningkatkan dukungan pemerintah terhadap perkembangan potensi kuliner lokal yang berkelanjutan, dengan pihak swasta dalam mendukung perkembangan potensi kuliner lokal, serta masyarakat yang mau meningkatkan potensi kuliner lokal yang dimiliki, baik dari segi higienis, kualitas dan cara pengepakan yang menarik sebagai oleh-oleh kuliner (something to buy) di DWE Desa Nyambu. 


\section{Daftar Pustaka}

Achols, John M. Hassan Shadily. 1984. Kamus Inggris Indonesia. Jakarta: Gramedia. Cet. XII.

Freddy Rangkuti. (2015) Analisis SWOT. Jakarta: PT Gramedia Pustaka Utama.

Hasan, M. Iqbal. (2002). Pokok-pokok Materi Metodologi Penelitian dan Aplikasinya. Bogor: Ghalia Indonesia.

Murphy, P. E. (1985). Tourism A Community Approach. Metheun: New York.

Prihadhi, Endra K. 2004. My Potensi. Jakarta: Elek Media Komputindo.

Pearce II, John A. dan Robinson Richard B.Jr. (2008). Manajemen Strategis 10. Salemba Empat: Jakarta

Sri Wahyuni, A. A. Nym. 2020. Pemberdayaan Masyarakat Dalam Pengembangan Desa Wisata Ekologis (DWE) Di Desa Nyambu

Kediri, Tabanan, Journey, Volume 3, Nomor 1.

Suwantoro. (1997). Dasar-Dasar Pariwisata. Yogyakarta: Penerbit Andi. Yoeti, O. A. (2001). Ilmu Pariwisata: Sejarah, Perkembangan dan Prospeknya. Jakarta: Pertja.

Undang-undang Nomor 10 Tahun 2009 tentang Kepariwisataan.

Surat Keputusan (SK) Bupati Tabanan Nomor 180/327/03/HK \& HAM/2016, Tentang Desa Nyambu sebagai Desa Wisata di Tabanan, pada tanggal 31 Oktober 2016.

https://bali.bisnis.com/read/20190103/537/875046/jumlah-desa-wisatadi-bali-meningkat-signifikan

https://theconversation.com/bagaimana-pariwisata-bali-harus-berbenahusai-pandemi-covid-19-137605

\section{Profil Penulis}

A. A. Ketut Sri Candrawati merupakan dosen di Program Studi Seni Kuliner Politeknik Internasional Bali Tabanan. Penulis menamatkan strata 1 di Program Studi Sastra Inggris di Universitas Warmadewa, kemudian strata 2 jurusan Administrasi di Universitas 17 Agustus 1945 Surabaya. Penulis memiliki ketertarikan pada topik-topik penelitian ilmu administrasi dan kuliner.

A. A. Nyoman Sri Wahyuni merupakan dosen di Program Studi Ilmu Administrasi Negara STISIP Margarana Tabanan. Penulis menamatkan strata 1 di Program Studi Ekonomi/ Akuntansi di Universitas Warmadewa, kemudian strata 2 pada Program Studi Ilmu Administrasi Negara di Universitas Jember dan kemudian melanjutkan ke jenjang Doktor di universitas Udayana Program Studi Kajian Budaya. Penulis memiliki ketertarikan pada topik-topik penelitian seputar sosial dan budaya. 
A. A. Ketut Sri Candrawati, A. A. Nyoman Sri Wahyuni 